\title{
4. 赤外線サーモグラフィ用連続撮影装置
}

\section{[目 的}

本装置の開発の目的は，時間的に温度分布が 変わる現象を，長時間連続的に記録する必要性 が増してきたためである。

これらは，医用サーモグラフィの応用分野が 抎大寸るにつれ，人体に刺激を与えた後の回復 過程，また薬郕の効果判定などに，従来も数多 くサーモグラフィが撮られてきた。それらの多 くは，ポラロイドを利用したものである.

そこでわれわれは, $35 \mathrm{~mm}$ カメラを利用し，そ のための全・半自動連続撮影装置を開発した。

\section{〔構成〕}

本装置は，日本電子製医用サーモグラフィ装 置（JTG-MAS）に装着するもので，電磁シャ ッター・ $35 \mathrm{~mm}$ カメラ (NICON-F)・マイクロ ニッコール $55 \mathrm{~mm}$ レンズ・拉よびフィルム巻 取り用モータードライブから構成される。 フィ ルムは，ILFORD，HP-4 を使用する。

\section{[撮影〕}

連続撮影システムは，全自動形と半自動形の 2 種類ある。

全自動形の作動は，走查開始のスタートパル スを利用し，電磁シャッターを介して，シャッ ターが開くように作られている，そして走査終 了時に，シャッターが閉じ，フィルムのコマ送 りがモータードライブで行なわれ，次いで次の 撮影の走查にはいる.
関東莪信病院麻酔科

村上正西坂剛

関東逓信病院写真室

三 並康宏

日 本 電 子 (株)

大月守

半自動形は，用手的に撮影開始可能となる.

この 2 種操作は，スイッチにより切り換えら れる。

\section{[特色・利点}

（1）経時的温度分布の変化の比較が容易であ る.

（2）最適な像がえられる.

連続的に撮影することにより，サーモグラフ 1像の最適な像が選択できる.

(3) 省 力 化

本装置を用い全自動形にし，撮影開始のスイ

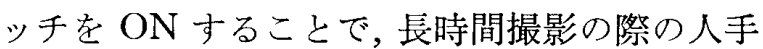
をはぶくことができる。

(4) サーモグラフィの消耗費の軽減

従来のポラロイドフィルムと $35 \mathrm{~mm}$ フィルム を比較すると，安価である．

（5）複写・拉大が容易

種々のサイズの複写・拡大ができ，また画質

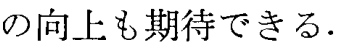

(6) シ 齐化

連続撮影した $35 \mathrm{~mm}$ フィルムを利用して，ア ニメーション手法により，シネ化ができる。シ ネ化により

（i）長時間の変化が短時間で観察可能であ る.

（ii）残像効果により，わずかな温度分布パ ターンの刻一刻と変化していく様子を観察で きる。

(7) 即 時 性 
ポラロイドにくらべ, $35 \mathrm{~mm}$ フィルムは, フ イルム現像, ペーパープリントが必要で処理時 間が長い欠点がある.しかし，サーモグラフィ 専用に暗室を作る場合，処理時間も短縮され る.

\section{[おわりに]}

本装置の用途として，医学界はもちろ九，工 業界にも大いに役立っていくと思われる.たと えば，自動車エンジンに扔いて，その発熱，お
よび冷却過程を本装置を用いて撮影し, その後 シネ化することにより, その温度変化を短時間 で観察することが可能である.

現在のところサーモグラフィの分析に抢ける 最終段階は, 結局, 写真処理によっていること から，本装置は $35 \mathrm{~mm}$ フィルムにサーモグラフ イを連続的に記録するという利点に加えささら にネガ・焼付け写真・スライドなど, 保存・再 生は抢もらがままにできるといらことからも， その有用性は高いと考えられる.

\title{
5. 精度の良い深部温度測定装置の理論と改良
}

\author{
東京大学工学部化学工学科 小 林 登 史 夫 \\ 東京医科歯科大学医用器材研究所
}

根本 鉄 神谷瞭 戸川達男

被験者の皮膚を傷つけず異和感もなしに，任 意の部位の深部温度を測定することは, 極めて 困難と考えられてきたが, 1970年英国のFox と Solmanによって新しい測定方法が提案され た．それは，体表面から体外の熱流を完全に遮 断すると, 体表面温度は樑部温と等しくなり， 深部温は皮膚温を測ることによって間接的に測 定できるという方法である. 基本原理は優れた ものであるが，実際にこの方法を用いて測定す ると, その測定精度に関し問題があることがわ かった. それは一般に $0.3^{\circ} \mathrm{C}$ 程度低い指示温を 示し, 室温など測定条件によって影響を受けや すいという精度の問題である. 媣部温度の部位 による偏差は通常 $2^{\circ} \mathrm{C}$ 以下であること，この誤 差は本測定方法の普及に致命的なものとなり得 る.そこで筆者らは以下に示すような検討と改 良を行ない，極めて精度の良い測定を可能にし た。

体表面に密着される深部温度測定器（プロー ブ） Fig. 1 に示すような新しい構造を持つも のにした．Fox らの作製したものに比べると断 熱材をとりまく金属（銅,アルミ等の熱良導体）

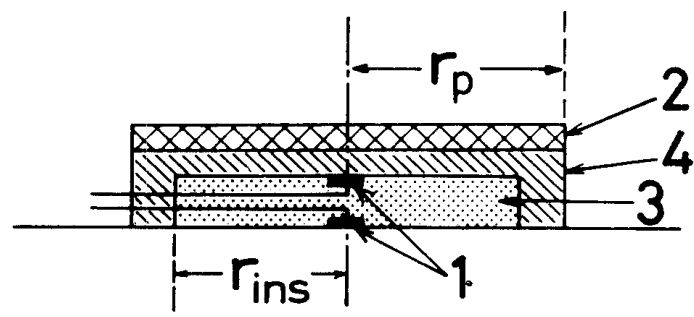

Fig. 1 改良型深部温度測定装置 (1: サーミスタ, 2;ヒータ, 3 ; 断 熱材, 4 ; 金属ブロック)

ブロックが追加された点が異なる．基本原理は 同じで，皮膚に対し垂直方向に断熱材をはさん で位置する 2 個の検温体（サーミス夕等）の指 示温度が等しくなるように外側をヒータで暖め る。すなおち，体表面において深さ方向の温 度勾配が零 $\left(\partial_{\mathrm{T}} / \partial_{Z}=0\right)$ となるため, 熱流が外 一出ることなく内部に貯ることになる.プロ ーブを皮膚に固定した際の皮下近傍の非定常熱 伝導の動向を皮下に厚さ $Z_{\mathrm{B}}$ の伝熱抵抗層（皮 下脂肪等）があると考え，深さ（z) と径 (r)の 2 次元の熱伀導方程式をHITAC-8700によって 数值計算した. 定常状態に達したのちのプロー ブ直下の皮膚温は，この計算によれば Fig. 2 に 